Federal Reserve Bank of Minneapolis

Research Department

\title{
The Co-Evolution of the Real and Financial Sectors in the Growth Process
}

\author{
John Boyd and Bruce Smith* \\ Working Paper 541 \\ Revised February 1996
}

Prepared for

World Bank Conference

on

"Stock Markets, Corporate Finance, and Economic Growth"

\begin{abstract}
We produce a theoretical framework that helps explain the co-evolution of the real and financial sectors of an economy in the growth process, as described by Gurley and Shaw. According to them, self-financed capital investment first gives way to debt finance and later to the emergence of equity as an additional instrument for raising funds externally. As the economy develops further, the aggregate ratio of debt to equity will generally fall. We analyze that portion of their account concerning the evolution of equity markets. We show that in an important sense, debt and equity are complementary sources for the financing of capital investments.
\end{abstract}

*Boyd, Federal Reserve Bank of Minneapolis and University of Minnesota; Smith, Federal Reserve Bank of Minneapolis and Cornell University. We thank Gerald Caprio, Doug Diamond, Ross Levine, and Asli Demirguc-Kunt for helpful comments, and Jason Schmidt for excellent research assistance. The views expressed herein are those of the authors and not necessarily those of the Federal Reserve Bank of Minneapolis or the Federal Reserve System. 


\section{Introduction}

Economists have long believed that financial markets and institutions are important factors in determining "The Wealth of Nations." In the last five years or so there has been a veritable renaissance of interest in this topic. This growing, recent literature has produced several important new reasons to think that financial institutions "matter" very much in the development process. Most of this research, however, considers economies with a very limited class of financial markets and often all investment is by assumption either financed entirely with debt, or entirely with equity. Debt and equity markets are therefore not active simultaneously. Moreover, with some exceptions, the level of activity in financial markets does not evolve along with the economy, and the status of various markets is often exogenously imposed. ${ }^{1}$

The treatment of financial markets in the modern theoretical literature is in sharp contrast with standard accounts of the role of financial markets in the growth process, such as that given by Gurley and Shaw $(1955,1960)$. They describe financial innovation as a dynamical process which both influences, and is influenced by the development of the real sector. In poor, primitive environments, they observe, capital formation is accomplished primarily with entrepreneurs' savings. As the economy grows, specialized lending institutions such as banks emerge and help finance additional capital investment. The loan claims produced in this process are held by the banks themselves and rarely traded. And, at this stage of development, entrepreneurs remain the only source of equity capital and are the sole residual claimants. With further increases in per capita income and wealth, markets for tradeable securities, both debt and equity, emerge and complement (but do not replace) bank lending.

Gurley and Shaw did not ignore the fact that technological innovation can affect financial arrangements. But technological change was not the center piece of their theory of finance and 
development. Rather, it was the endogenous, dynamical interaction of the financial and real sectors. Their account of events is well supported by the data. Michie (1987) and Gurley and Shaw (1967) show how equity market development was strongly associated with real development in the history of the United States and the United Kingdom. And Antje and Jovanovic (1992) and Demirguc-Kunt and Levine (1993, 1994) demonstrate that measures of equity market activity are positively correlated with measures of real activity, across different countries (and that the association is particularly strong for developing economies). Such observations are supported by the data reported in Table 1.

The objective of this study is to provide a better understanding of the co-evolution of the real and financial sectors of an economy as it moves along a growth path. We are particularly interested in whether it is possible to produce a theoretical framework that stylistically reproduces the evolution of financial markets in the growth process. We focus here especially on the emergence and development of equity markets, and we put particular emphasis on three main questions: (1) Why does the development of equity markets occur relatively late in the development process?; (2) When this development occurs, what social costs and what social benefits result?; and (3) What kinds of government policy actions are likely to foster or inhibit the development of equity markets? These questions are clearly of central importance in the context of economic development: as Levine and Zerros (1995) demonstrate, measures of equity market activity are very strongly correlated with measures of real economic performance.

Since our focus here is on the interactions between real development, equity market development, and the financing of capital investment, we clearly must pose these questions in an environment which allows for growth and capital accumulation. In addition, we need a model in which capital accumulation is financed externally through a combination of debt and equity - 
and in which the level of development of debt and equity markets itself affects investment behavior. Such a model is developed and formally analyzed in Boyd and Smith (1994d, 1995); here we sketch the main components and results of their analysis. We then use that analysis as a basis for a discussion of how a variety of different government policy activities might impact on the development of equity markets.

\section{Overview and Summary of Findings}

Clearly the composition of the external finance that investors-and firms more generally -obtain represents the solution to a constrained minimization problem. Given the quantity of external finance required, and given constraints on the availability of certain kinds of finance, entrepreneurs will raise external funding in the lowest cost way. Of course in practice the cost of external funds depends on a number of factors, including the level of "market" interest rates, the existence of various taxes, and the existence of various subsidies implicit in things like government credit or loan guarantee programs. It is these factors that suggest why government policy can be expected to impact on the level of activity in equity markets.

The issue of what is the "lowest-cost" way of raising external funding is of necessity a somewhat subtle one, however. Modigliani and Miller (1958), for example, described circumstances under which the composition of a firm's liabilities is completely irrelevant to the

cost of obtaining external funding. Obviously, any theory that can successfully address why equity market development and real development are related must find a way of evading this implication of the justly celebrated Modigliani-Miller Theorem.

A common formulation that does evade the Modegliani-Miller Theorem, and often delivers a determinate liability structure, is the introduction of so-called "bankruptcy costs." These costs 
are incurred when entrepreneurs cannot make contractual payments to creditors. Since the contractual payments called for by debt are not contingent on firm performance, whereas those called for by equity are, it is intuitive that the composition of a firm's debt and equity affects the probability of bankruptcy and hence expected bankruptcy costs. The composition of a risk neutral firm's external finance will be chosen to minimize the expected costs of raising funds externally, inclusive of these bankruptcy costs.

Under a theory of this type, if the role of debt and equity is changing over time, and with the level of development, it must be the case that entrepreneurs are perceiving corresponding changes in bankruptcy costs. But what are these changes, and why should they occur in a systematic way across different countries and time periods with the process of economic development? An answer to this question requires that we take a stand on the nature of these bankruptcy costs.

Fortunately, a well-developed model of the micro-economic foundations of bankruptcy costs exists, and we will exploit that model here. Specifically, we employ a standard costly state verification (CSV) model of the type originally developed by Townsend (1979), and subsequently extended by Diamond (1984), Gale and Hellwig (1985), and Williamson (1986). In this model, some component of a firm's returns can be observed by external creditors only by bearing a (fixed) cost. So long as the firm honors its contractual commitments there is no need to "monitor" the firm's returns, and these costs are not incurred. On the other hand, when the firm cannot honor its commitments, external creditors must verify the firm's returns, and doing so implies that costs are incurred. This provides a physical story about bankruptcy costs.

In the most standard CSV environments, ${ }^{2}$ it is the entire set of firm returns that is unobservable. This fact has a strong implication. Since equity claims promise payments based 
on firm performance, and since firm performance is costly to observe, the use of equity would require that excessive verification costs be incurred. It is therefore optimal for firms to be 100 percent debt-financed. Indeed debt claims make contractual payments contingent on firm performance only in the event of a bankruptcy, and therefore the use of debt minimizes expected verification costs.

Clearly the kind of model just described cannot be adequate for our purposes, since it predicts that equity markets will never be active. However, the CSV environment does provide a simple and tractable explicit model of bankruptcy costs. Therefore, we pursue the implications of a CSV model altered in one basic way. Whereas the conventional CSV literature gives investors access to only a single investment technology with unobservable returns, we give investors access to two technologies. In particular, we assume that physical capital can be produced using either of two technologies. One yields a return which is freely observable only by the initiating investor, and hence is subject to a CSV problem. The other yields a return which is freely observable to all agents. Under the assumption that the expected amount of capital produced (exclusive of verification costs) by the former technology exceeds that produced by the latter, ${ }^{3}$ agents undertaking capital investments face a trade-off. The technology with the unobservable return is intrinsically more productive, but it is also associated with larger bankruptcy costs. Our analysis allows capital producers to make a choice as to how heavily they will utilize each technology; clearly this choice will depend on the relative expected returns on the two technologies, and on the perceived costs of state verification. When the perceived costs of verification are low, the unobservable return technology will be particularly attractive, and its higher expected return implies that-when costs are perceived to be low enough-it will be utilized exclusively. In this event our model mimics the conventional CSV environment, and 
expected verification costs are minimized by having firms be 100 percent debt-financed. Equity markets will not be active.

As the perceived costs of state verification rise, it will eventually became economical for capital producers to take actions to reduce the expected costs of state verification. The action they can take is to utilize more heavily the observable return investment technology. The higher perceived verification costs are, the more heavily the observable return technology will be utilized. Because the return on this technology is observable, it is not costly to issue claims which bear payments contingent on some aspects of firm performance, and hence some use of equity can be optimal. At the same time, so long as the unobservable return technology is in use at all, the expected verification costs associated with it must be minimized. To do so, firms will continue to issue some debt. Indeed, as we demonstrate formally below, the minimization of expected verification costs will dictate that firms issue a determinate amount of debt and equity. Moreover, the issue of some equity-when equity is used-reduces the cost of issuing debt. In this important sense equity finance is not just a substitute for debt finance, but rather complements debt finance. This theoretical result is consistent with many empirical findings, such as those of Demirguc-Kunt and Levine (1994), Rojas-Suarez and Weisbrod (1994), and Demirguc-Kunt and Maksimovic (1995) suggesting the complementary nature of debt and equity market activity in firm financing decisions, and in the general process of development.

According to the story we have just told, a volume of equity market activity that increases as an economy develops must be observed because capital producers are more actively utilizing the observable return technology in an effort to reduce the expected costs of state verification. Why should they be expected to utilize this technology more intensively as an economy becomes 
more developed? Clearly they will do so if and only if the perceived costs of state verification rise along with the development process.

In the model we describe below, entrepreneurs perceive relative verification costs that rise during the development process for the following reason. Entrepreneurs are engaged in the production of physical capital. As an economy moves along a growth path, we typically expect the relative price of capital to fall, a proposition that is supported by a wealth of empirical evidence (see for example, Greenwood et al. 1995). Suppose that state verification technologies utilize some combination of inputs, possibly capital and labor. The relative price of labor will rise in the development process, and certainly will rise relative to the price of capital. As a consequence, the costs of state verification must rise relative to the value of what entrepreneurs produce as an economy develops. This rise in perceived costs will, as we have argued, induce firms to utilize the observable return technology more intensively, and to raise more of their funds in equity markets. And there is good evidence both that less-developed economies have higher per unit costs of bankruptcy (World Development Report 1989), and that their firms rely more heavily on equity markets (Demirguc-Kunt and Maksimovic 1995, Levine and Zerros 1995).

While we think that this story is itself highly plausible, the intuition underlying it depends on few details of the model we present. Indeed, an intuitively simpler (but formally more complex) story is that development is associated with the use of increasingly more specialized and complex technologies. Thus, as economies develop, external monitoring becomes more difficult, ceteris paribus, and as a result, firms take more actions to economize on these costs. This kind of thinking will generate the same conclusions we have just described. 
Our analysis also suggests that economies that are more developed will have less severe financial market frictions, in a particular sense, than do less developed economies. This appears to be consistent with observation (World Development Report 1989), and indeed it is often argued (for example, by McKinnon 1973 and Shaw 1973) that less developed economies are less developed because their financial market frictions are more severe than those of their more developed counterparts. In all our examples, ${ }^{4}$ economies that are "farther along their growth paths" lose fewer resources (per unit of funding) due to the presence of intermediation costs than do less mature economies. This is the social benefit yielded by the development of equity markets. Importantly, this is an endogenous outcome; financial market frictions become less severe over time as a natural consequence of development. In this sense, the evolution of financial markets in the development process does tend to provide an economy with a more efficiently functioning set of capital markets.

Finally, our results provide several suggestions about the consequences of various government policies, both for the level of real activity, and for the level of activity in equity markets. After pursuing the formal analysis, we offer an informal discussion of how various policy actions might affect capital accumulation, and equity market activity. We focus particularly on policies that affect the opportunity costs of external finance, as many government policies do in practice. The analysis of how such policies affect both the financial system, and the level of real activity, has not previously been undertaken in a formal way. Our results indicate that government policies that lower the opportunity cost of external funds should be expected to attenuate equity market development. A particular finding is that high inflationwhich acts to reduce real interest rates-will interfere with the development of equity market activity. Again, such a finding is well supported empirically (Boyd, Choi, and Smith 1995). • 


\section{The Model Environment}

In this section we lay out a model that formalizes the intuition described in section 2 . Specifically, we consider an economy populated by a sequence of two-period lived, overlapping generations, plus an initial old generation. Each generation has the same large population, and is identical in its composition. In particular, agents in each young generation are divided into two types, which we term "borrowers" and "lenders." All borrowers [lenders] are identical, ex ante, and borrowers [lenders] constitute a fraction $\alpha \in(0,1)[1-\alpha]$ of the population. Lenders are endowed with one unit of labor when young, which they supply inelastically. They are retired when old. Borrowers are endowed with no labor, but are endowed with access to high-return investment projects, which are described below. All agents, both borrowers and lenders, are risk neutral and care only about old period consumption; thus, all young period income is saved.

There is a single consumption good at each date, which is produced according to a standard, commonly available constant returns to scale production function with capital and labor as inputs. In particular, if $\mathrm{K}_{\mathrm{t}}$ is the time $\mathrm{t}$ capital stock and $\mathrm{L}_{\mathrm{t}}$ is the time $\mathrm{t}$ labor input, then the production of final goods and services is given by $F\left(K_{t}, L_{t}\right)$. In addition, if $k_{t} \equiv K_{t} / L_{t}$ is the capital-labor ratio at $t$, then $f\left(k_{t}\right) \equiv F\left(k_{t}, 1\right)$ is the intensive production function. We maintain standard assumptions on $f$; that is $f(0) \geq 0, f^{\prime}(k)>0>f^{\prime \prime}(k)$ for all $k \geq 0$, and that $f$ satisfies the usual Inada conditions. For simplicity, we also assume that capital is used in production and then depreciates completely. 


\section{Capital Production Technologies}

Our assumptions imply that agents who can produce capital (borrowers or "entrepreneurs") require external funding in order to do so. Our primary focus is on whether they raise this funding through debt or equity markets, and on the extent to which each set of markets is utilized. As argued in section 2, an interesting analysis of this question requires that some type of "bankruptcy cost" be present. We therefore assume that capital can be produced at each date using one or more of the following three technologies:

1. There is a commonly available, nonstochastic linear technology whereby one unit of current output invested at $t$ yields $r>0$ units of capital at $t+1$. In addition, there are two stochastic linear technologies that convert current output into future capital.

2. Technology o (for observable return) produces y units of capital at $t+1$ per unit invested at $t$, where $\mathrm{y}$ is an iid (across agents and across time periods) random variable, realized at $\mathrm{t}+1$. We assume that $\mathrm{y} \in\left\{\mathrm{y}_{1}, \mathrm{y}_{2}, \ldots, \mathrm{y}_{\mathrm{N}}\right\}$, and we let $\mathrm{p}_{\mathrm{n}} \equiv \operatorname{prob}\left(\mathrm{y}=\mathrm{y}_{\mathrm{n}}\right)$. Obviously $0 \leq \mathrm{p}_{\mathrm{n}} \leq 1$ for all $\mathrm{n}$, and $\Sigma \mathrm{p}_{\mathrm{n}}=1$. Finally, we assume that for any investor the amount of capital yielded by investments in technology o is publicly observable at zero cost.

3. Technology $u$ (for unobservable return) is assumed to produce w units of capital at $t+1$ per unit invested at $t$. $w$ is a continuous, iid (across investors and periods) random variable with cdf $G$ and pdf $g$. $g$ is continuously differentiable with support $[0, \bar{w}]$. In addition, the return on investments in technology $u$ can be observed (by any agent other than the initiating investor) only by bearing a fixed cost of $\gamma>0$ units of the current consumption good. Thus

a CSV problem arises for investments in technology u.

We assume that only borrowers are endowed with access to the investment technologies o and $u$, and ownership of these investment opportunities cannot be traded. Moreover, we impose 
an upper bound on the scale at which any borrower can operate the investment technologies. Thus we let $i_{t}^{o}\left(i_{t}^{u}\right)$ be the investment in technology o $(u)$ by a representative borrower at $t$, and we let $i_{t} \equiv i_{t}^{o}+i_{t}^{u}$. Then each borrower faces the maximum scale of operation constraint $i_{t} \leq$ $\mathrm{q}$, where $\mathrm{q}$ is an exogenously given parameter. The assumption of linear capital production technologies, along with the existence of an upper bound on their operation will make it easy to determine how much external finance each entrepreneur desires. Finally, we define $\theta_{t} \equiv i_{t}^{o} / i_{t}$ to be the fraction of total investment done in technology o by a representative borrower.

Define $\hat{y} \equiv \sum_{n} p_{n} y_{n}$ to be the expected gross return (in units of capital) on investments in technology $\mathrm{o}$, and $\hat{\mathrm{w}} \equiv \int_{0}^{\bar{W}} \mathrm{wg}(\mathrm{w}) \mathrm{dw}$ to be the expected gross return (in units of capital), not inclusive of verification costs, on investments in technology $u$. We assume that $\hat{w}>\hat{y}>r$. Thus the commonly available technology is relatively unproductive. It should be clear that, unless $\hat{w}>\hat{y}$ holds, the unobservable return technology will never be employed.

Finally, we assume that the initial old agents are endowed with $\mathrm{K}_{\mathrm{o}}>0$ units of capital, per capita. No agents thereafter are endowed with either capital, or the consumption good.

\section{Trade and Finance}

Two kinds of trade take place in this economy: capital and labor are rented in competitive factor markets, and funds are transferred from lenders to borrowers. The inherited capital stock (the proceeds of the previous period's investment) and labor are both supplied inelastically. Both factors are demanded by competitive producers, and hence are paid their marginal products. Thus if $\omega_{\mathrm{t}}$ is the time $\mathrm{t}$ real wage rate and $\rho_{\mathrm{t}}$ is the time $\mathrm{t}$ rental rate for capital, we have 
(1) $\quad \rho_{\mathrm{t}}=\mathrm{f}^{\prime}\left(\mathrm{k}_{\mathrm{t}}\right)$

(2) $\quad \omega_{t}=f\left(k_{t}\right)-k_{t} f^{\prime}\left(k_{t}\right) \equiv \omega\left(k_{t}\right)$

Clearly, $\omega^{\prime}\left(k_{t}\right)>0$ holds, for all $k_{t}$.

We assume throughout that the potential supply of funds by lenders is at least as great as the demand for funds by borrowers. The supply of funds by lenders is $(1-\alpha) \omega_{t}$ at $t$, since lenders save their entire young period income. The maximum demand for funds by borrowers is $\alpha \mathrm{q}$. Hence we assume that

$$
(1-\alpha) \omega\left(\mathrm{k}_{\mathrm{t}}\right) \geq \alpha \mathrm{q}
$$

for all "relevant" values of $k_{t}$. When (3) holds, any marginal savings must be invested in the commonly available technology, yielding $\mathrm{r}$ units of capital per unit invested. Thus the opportunity cost of funds faced by lenders at $t$ must equal $r_{t+1}$, since the rental value of the capital obtained at $t+1$ is $\rho_{t+1}$.

\section{Funding Contracts Between Borrowers and Lenders}

-A funding contract specifies a quantity of resources that will be transferred to a particular borrower $\left(i_{b}\right)$, as well as how these resources will be allocated among technologies o and $u .^{5}$ In addition, the contract specifies a set of payments that are contingent on firm performance. Since the return $y$ is observable, repayments can always be made contingent on it. However, since the return w can be observed externally only if monitoring (or verification) occurs, repayments can only meaningfully be made contingent on $\mathrm{w}$ if state verification occurs. Hence a contact must specify a set of states $A_{t}(y),\left(B_{t}(y)\right)$ in which monitoring will (will not) occur at $t+1$. This set can obviously be conditioned on y. In monitoring states only, repayment can also be 
made contingent on $w$. We let $R_{t}(w, y)$ be the promised repayment at $t+1$, in units of time $\mathrm{t}+1$ consumption and per unit borrowed, if monitoring occurs at that date. In addition, we let $x_{t}(y)$ be the promised repayment at $t+1$, in units of time $t+1$ consumption and per unit borrowed, if monitoring does not occur.

Funding contracts are assumed to be announced by borrowers, and such contracts are then either accepted or rejected by lenders. In order to avoid rejection, such contracts must satisfy the following three constraints.

1. Contracts must be feasible or, in other words, specify nonnegative consumption levels for borrowers. Thus a borrower's repayment can never exceed his total available resources, or

(4.a) $\quad \mathrm{R}_{\mathrm{t}}(\mathrm{w}, \mathrm{y}) \leq \rho_{\mathrm{t}+1}\left[\theta_{\mathrm{t}} \mathrm{y}+\left(1-\theta_{\mathrm{t}}\right) \mathrm{w}\right]$

(4.b) $\quad \mathrm{x}_{\mathrm{t}}(\mathrm{y}) \leq \rho_{\mathrm{t}+1}\left[\theta_{\mathrm{t}} \mathrm{y}+\left(1-\theta_{\mathrm{t}}\right) \mathrm{w}\right], \quad$ for all $\mathrm{w} \in \mathrm{B}_{\mathrm{t}}(\mathrm{y})$

must hold. Note that $\rho_{t+1}$ appears as it does in (4) since investment returns are in units of capital, while repayments are in units of consumption.

2. Contracts must be incentive compatible, so that borrowers have an incentive to announce truthfully when a monitoring state has occurred. They will do so if and only if repayments are lower in monitoring than in nonmonitoring states, or if and only if

$$
\mathrm{R}_{\mathrm{t}}(\mathrm{w}, \mathrm{y}) \leq \mathrm{x}_{\mathrm{t}}(\mathrm{y}), \quad \text { for all } \mathrm{w} \in \mathrm{A}_{\mathrm{t}}(\mathrm{y}) .
$$

3. Since lenders can always invest in the commonly available technology, the expected repayment-per unit borrowed-must at least equal the opportunity cost of funds $\left(r \rho_{t+1}\right)$ plus expected monitoring costs (which without loss of generality we assume are born by lenders). Thus contractual repayments must satisfy the expected return constraint ${ }^{6}$ 
(6)

$$
\begin{gathered}
\left\{\sum_{n} p_{n} \int_{w \in A_{t}\left(y_{n}\right)} R_{t}\left(w, y_{n}\right) g(w) d w+\sum_{n} p_{n} \int_{w \in B_{1}\left(y_{n}\right)} x_{t}\left(y_{n}\right) g(w) d w\right\} i_{t} \\
-\gamma \sum_{n} p_{n} \int_{w \in A_{t}\left(y_{n}\right)} g(w) d w \geq r \rho_{t+1} i_{t} .
\end{gathered}
$$

Borrowers announce funding contract terms to maximize their own expected utility, subject to the constraints (4)-(6). The expected utility of a borrower is simply the expected return on the borrower's investments, less the expected repayment implied by the contract. Thus borrowers choose contract terms to maximize

$$
i_{t}\left\{\rho_{t+1}\left[\theta_{t} \hat{y}+\left(1-\theta_{t}\right) \hat{w}\right]-\sum_{n} p_{n} \int_{w \in A_{t}\left(y_{n}\right)} R_{t}\left(w, y_{n}\right) g(w) d w-\sum_{n} p_{n} \int_{w \in B_{t}\left(y_{n}\right)} x_{t}\left(y_{n}\right) g(w) d w\right\}
$$

subject to (4)-(6).

This completes the specification of the model environment and the description of how agents behave. We now need to describe the solution to the contracting problem of borrowers as a prelude to an analysis of the evolution of the capital stock, real activity, and the volume of equity market transactions.

\section{The Nature of Equilibrium Contracts}

Boyd and Smith (1994d) show that equilibrium contracts between borrowers and lenders have the following properties. First, borrowers operate their investment projects at the largest possible scale, so that $i_{t}=q$. There is no reason for them not to do so, since the fact that $\hat{y}>\mathrm{r}$ implies that unutilized capacity can always be profitably exploited. Second, if the 
borrower's ex post return $\left[\theta_{\mathrm{t}} \mathrm{y}+\left(1-\theta_{\mathrm{t}}\right) \mathrm{w}\right] \rho_{\mathrm{t}+1}$ is no less than the promised payment $\mathrm{x}_{\mathrm{t}}(\mathrm{y})$, then it is feasible for borrowers to fully meet their external commitments and to avoid state verification. Verification costs are minimized by doing just that. Third, if the ex-post return is less than $x_{t}(y)$, then it is not feasible for borrowers to meet their contractual commitments. In this case providers of external funding monitor the firm, learn the true value of $w$, and retain the entire value of the firm's output. All of these results are direct analogs of findings in conventional CSV models (Diamond 1984; Gale-Hellwig 1985; and Williamson 1986).

It will now be useful to define a new variable. Let

$$
\mathrm{z}_{\mathrm{nt}} \equiv\left\{\left[\mathrm{x}_{\mathrm{t}}\left(\mathrm{y}_{\mathrm{n}}\right) / \rho_{\mathrm{t}+1}\right]-\theta_{\mathrm{t}} \mathrm{y}_{\mathrm{n}}\right\} /\left(1-\theta_{\mathrm{t}}\right)
$$

Formally, $z_{n t}$ is the smallest possible realization of $w$, conditional on $y=y_{n}$, that enables an entrepreneur to meet his contractual commitments, and to avoid verification. In other words, if $y=y_{n}$ at $t$, then monitoring occurs if and only if the return on technology $u$ is less than $z_{n t}$. In effect, then, the variables $z_{n t}$ govern the conditional probability (and expected cost) of state verification. If $y=y_{n}$ at $t$, the probability of monitoring is just $G\left(z_{n t}\right)$. In addition, since w and $y$ are independent, if the borrower's optimization problem displays enough concavity, borrowers will wish to smooth monitoring costs across realizations of $y$. Hence $z_{1 t}=z_{2 t}=\ldots=z_{N t}=$ $z_{t}$ holds, and the probability of state verification, $G\left(z_{t}\right)$, will be independent of the realization of $y$. Thus the variable $z_{t}$ indexes the amount of state verification that is associated with a particular contract.

The optimal value of $z_{t}$ depends on two endogenous factors. First, it depends on the composition of a borrower's investment between technologies o and $\mathrm{u}$; that is on $\theta_{\mathrm{t}} \equiv \mathrm{i}_{\mathrm{t}}^{\mathrm{o}} / \mathrm{i}_{\mathrm{t}}$. Note that this is chosen by the borrower. The higher is $\theta_{\mathrm{t}}$, the more investment is done in the 
observable return technology. This permits less monitoring to occur, so that higher values of $\theta_{\mathrm{t}}$ are associated with lower values of $\mathrm{z}_{\mathrm{t}}$. Second, $\mathrm{z}_{\mathrm{t}}$ depends on the relative cost of monitoring, $\psi_{\mathrm{t}+1} \equiv \gamma / \mathrm{q} \rho_{\mathrm{t}+1} \cdot{ }^{7}$ This is taken as parametric by the borrower, but it is endogenous to the economy. To denote the dependence of $z_{t}$ on $\theta_{t}$ and on $\psi_{t+1}$, we write $z_{t}=z\left(\theta_{t} ; \psi_{t+1}\right) . \quad z\left(\theta_{t} ;\right.$ $\left.\psi_{\mathrm{t}+1}\right)$ must be chosen, given $\theta_{\mathrm{t}}$ and $\psi_{\mathrm{t}+1}$, so that providers of external funding receive the market expected return $\left(r \rho_{t+1}\right)$ on their investments at $t$.

As we have argued, the probability of monitoring is simply $\mathrm{G}\left(\mathrm{z}_{\mathrm{t}}\right)=\mathrm{G}\left[\mathrm{z}\left(\theta_{\mathrm{t}} ; \psi_{\mathrm{t}+1}\right)\right]$. It is then easy to show that entrepreneurs then want to choose $\theta_{\mathrm{t}}$ to maximize the expression

$$
\mathrm{q} \rho_{\mathrm{t}+1}\left\{\theta_{\mathrm{t}} \hat{\mathrm{y}}+\left(1-\theta_{\mathrm{t}}\right) \hat{\mathrm{w}}-\mathrm{r}-\psi_{\mathrm{t}+1} \mathrm{G}\left[\mathrm{z}\left(\theta_{\mathrm{t}} ; \psi_{\mathrm{t}+1}\right)\right]\right\}
$$

In particular, $\mathrm{q} \rho_{\mathrm{t}+1}\left[\theta_{\mathrm{t}} \hat{\mathrm{y}}+\left(1-\theta_{t}\right) \hat{\mathrm{w}}\right]$ is the expected amount of capital produced, valued at the market price of capital. $q \rho_{t+1} r$ is the expected return that must be offered to obtain $q$ units of funds, and $\mathrm{q}_{\mathrm{t}+1} \psi_{\mathrm{t}+1} \mathrm{G}\left[\mathrm{z}\left(\theta_{\mathrm{t}} ; \psi_{\mathrm{t}+1}\right)\right]$ represents the expected costs of state verification. Each borrower chooses $\theta_{\mathrm{t}}$ to maximize the expression in (9). That expression clearly reflects the following trade-off: higher values of $\theta_{\mathrm{t}}$ reduce the expected amount of capital produced, but they also reduce the probability of monitoring, $\mathrm{G}\left[\mathrm{z}\left(\theta_{\mathrm{t}} ; \psi_{\mathrm{t}+1}\right)\right]$. The higher is $\psi_{\mathrm{t}+1}$, the greater is the value of a reduction in monitoring costs; hence we expect the optimal choice of $\theta_{t}$ to rise with $\psi_{\mathrm{t}+1}$. To denote the relation between the choice of $\theta$ and the scaled monitoring $\operatorname{cost} \psi$, let $\theta^{*}(\psi)$ denote the borrower's optimal choice of $\theta$. Boyd and Smith (1994d) describes formal conditions under which the intuition above is valid, and in particular under which

$$
\mathrm{d} \theta * / \mathrm{d} \psi \geq 0
$$


The solution to the borrower's problem is completely summarized by the composition of investment $\left[\theta_{\mathrm{t}}^{*}=\theta\left(\psi_{\mathrm{t}+1}\right)\right]$, by the amount of monitoring called for $\left[\mathrm{z}_{\mathrm{t}}^{*}=\mathrm{z}\left(\theta_{\mathrm{t}}^{*} ; \psi_{\mathrm{t}+1}\right)\right]$, and by the repayment schedules $x_{t}(y)$ and $R_{t}(w, y)$. Once the borrower's problem has been solved, however, we are left with the further problem of how the optimal contract can be supported in the marketplace. We now describe how an optimum can be implemented by having borrowers issue an appropriate mix of debt and equity.

\section{A. Supporting an Optimum by Issuing Debt and Equity}

An optimal funding contract calls for a repayment rate of $x_{t}(y)$ if state verification does not occur at $\mathrm{t}+1$, where

$$
\mathrm{x}_{\mathrm{t}}(\mathrm{y})=\rho_{\mathrm{t}+1}\left[\left(1-\theta_{\mathrm{t}}^{*}\right) \mathrm{z}\left(\theta_{\mathrm{t}}^{*} ; \psi_{\mathrm{t}+1}\right)+\theta_{\mathrm{t}}^{*} \mathrm{y}\right]
$$

Notice that this promised repayment consists of the sum of two terms; one $\left[\rho_{\mathrm{t}+1}\left(1-\theta_{\mathrm{t}}^{*}\right) \mathrm{z}\left(\theta_{\mathrm{t}}^{*} ; \psi_{\mathrm{t}+1}\right)\right]$ which is not contingent in any way on firm performance, and another $\left(\rho_{\mathrm{t}+1} \theta_{\mathrm{t}}^{*} \mathrm{y}\right)$ which depends on the observable component of firm performance (y). Standard usages of the terms ${ }^{8}$ direct us to label the first component "as the return to debt-holders" in nonmonitoring states, while the second component is labeled the return to equity-holders.

In order to determine the amount of debt and equity issued by a representative firm, it is necessary to determine how monitoring responsibilities are allocated between debt and equityholders. Following standard interpretations, we assume that debt-holders are "paid first." If it is infeasible to make the promised total payment to debt-holders (which is $\left.\mathrm{q}\left(1-\theta_{\mathrm{t}}^{*}\right) \mathrm{z}\left(\theta_{\mathrm{t}}^{*} ; \psi_{\mathrm{t}+1}\right) \rho_{\mathrm{t}+1}\right)$, then debt-holders monitor and become residual claimants on investment returns. If the returns on investments are large enough to repay debt-holders, but not large 
enough to fully repay both debt and equity holders (in the amount $\mathrm{qx}_{t}(\mathrm{y})$ ), then debt-holders are fully repaid while equity-holders receive less than promised. Equity-holders then verify the return and retain all firm income (net of monitoring costs), less payments to debt-holders. We assume that both debt and equity-holders can coordinate their monitoring activity, thereby avoiding duplication of monitoring effort.

This interpretation of monitoring-and of which agents perform it-is inconsistent with the standard terminology employed in the existing CSV literature in one significant way. Specifically, equity-holders cannot literally be construed as forcing firms into bankruptcy proceedings, and therefore we should no longer refer to all states in which monitoring occurs as "bankruptcy states." Nonetheless, the interpretation that some monitoring is done by equityholders does reflect what is often observed in practice when firms experience low profits, but are still able to cover their payments of principle plus interest. Under these circumstances there is likely to be a conflict between the outside equity-holders and the inside owner-managers. Outside equity-holders cannot force bankruptcy, but they can undertake a variety of costly actions against inside owner-managers which, among other things, have the effect of uncovering information about the firm. Such actions include the hiring of outside auditors, various attempts to force changes in firm policies, or even attempts to replace the incumbent management. These kinds of actions may be channeled through the board of directors, or even through formal class action suits, and hence are coordinated among external equity-holders. In the model all of these activities are, of necessity, represented by costly monitoring.

Given these allocations of payments and monitoring responsibilities among debt and equityholders, the quantities of debt and equity issued by any borrower are determined by two considerations. First, the real value of debt $\left(d_{t}\right)$ and equity $\left(e_{t}\right)$ issued at $t$ must raise the 
necessary external funds (that is, $i_{t}=q=d_{t}+e_{t}$ must hold). Second, both debt and equityholders must obtain the market expected return $\left(r \rho_{t+1}\right)$ between $t$ and $t+1$ on their assets. These two sets of conditions completely determine $d_{t}$ and $e_{t}$. Loosely speaking, it is economical to issue equity only when technology o is utilized. Thus, if $\theta_{t}=0$, so too does $e_{t}=0$. By the same token, debt is employed to minimize the verification costs associated with technology $u$. Thus, if $\theta_{\mathrm{t}}=1$, no debt is required, and $\mathrm{e}_{\mathrm{t}}=\mathrm{q}$ (the firm is 100 percent equity financed). For values of $\theta_{\mathrm{t}}$ between zero and one, higher values of $\theta_{\mathrm{t}}$ are generally associated with greater use of equity, for given values of the relative monitoring cost parameter $\psi_{\mathrm{t}+1}$.

It is also true that, for given values of $\theta_{t}$, higher values of $\psi_{t+1}$ (higher monitoring costs) tend to be associated with less use of equity. (See Boyd and Smith 1994d for a formal statement.) Of course when $\psi_{t+1}$ rises, in general, entrepreneurs will be induced to take actions to further economize on state verification, so that $\theta_{\mathrm{t}}^{*}$ will rise as well. This tends to increase the volume of equity issued. Thus, theoretically, the net effect of higher values of $\psi_{\mathrm{t}+1}$ on the volume of equity issued is ambiguous. Examples produced by Boyd and Smith (1994d, 1995) suggest that, when $\psi_{t+1}$, rises, we should typically expect $\theta\left(\psi_{t+1}\right)$ to rise enough so that firms increase their reliance on equity finance. Or, in other words, it is reasonable to expect that higher perceived monitoring costs lead to the increasingly heavy utilization of technology o. Since investment in this technology is associated with the use of equity, higher perceived monitoring costs are also typically associated with a greater volume of equity market activity.

\section{General Equilibrium: The Evolution of the Real and Financial Sectors}

In this section, we integrate the analysis of firm investment and financing choices into a conventional neoclassical growth model of the Diamond (1965) variety. The result is a quite 
standard one-sector growth model, with one exception. As in most one-sector growth models, starting from some initial capital stock, the economy will (under one technical condition) converge monotonically to a steady state capital stock and output level. Again, as in most (one and two sector) growth models, the accumulation of capital will imply that the marginal product of capital, and hence its relative price, declines as an economy moves along its growth path.

In our model, this decline in the relative price of capital has three closely related implications that are not present in more standard models. First, entrepreneurs are engaged in the production of capital, but state verification consumes final goods and services. ${ }^{9}$ Thus the relative price of what entrepreneurs produce falls relative to the cost of monitoring or, in other words, the perceived relative cost of monitoring rises in the development process. Second, as we have argued, this causes entrepreneurs to shift the composition of investment towards the observable return technology, in order to economize on (increasingly expensive) state verification. This shift in the composition of investment is typically associated with the increasingly heavy use of equity markets. And third, as the composition of investment changes, less monitoring occurs, and the quantity of resources consumed by the presence of the CSV problem declines. This is the social benefit associated with the development of equity markets, and it conforms to the observation that the development of direct transactions in securities tends to reduce the costs of intermediation (Watson et al, 1986).

Of course this benefit is only gained at some cost. The shift in the composition of investment implies that less capital is being produced over time per unit invested. It is this cost (which is highest when the capital stock is relatively low, and capital has a high relative price) which prevents large levels of equity market activity early in the development process. We now formalize this intuition. 


\section{A. Capital Accumulation and Production}

If the time $t$ capital-labor ratio is $k_{t}$, then each young lender earns $\omega\left(k_{t}\right)$, all of which is saved. Hence per capita savings is $(1-\alpha) \omega\left(\mathrm{k}_{\mathrm{t}}\right)$. Each young borrower seeks to obtain $\mathrm{q}$ units of funds, and hence the per capita demand for external funding is $\alpha \mathrm{q}$.

In equilibrium, any savings in excess of $\alpha \mathrm{q}$ must be invested in the publicly available capital production technology. Hence the level of investment in this technology is-in per capita terms $-(1-\alpha) \omega\left(\mathrm{k}_{\mathrm{t}}\right)-\alpha \mathrm{q}$, and the quantity of capital at $\mathrm{t}+1$ produced using this technology is $\mathrm{r}\left[(1-\alpha) \omega\left(\mathrm{k}_{\mathrm{t}}\right)-\alpha \mathrm{q}\right]$. In addition, of the $\alpha \mathrm{q}$ units of funds obtained by borrowers, a fraction $\theta_{\mathrm{t}}^{*}$ is invested in technology $o$ at $t$, yielding $\hat{y}$ units of capital per unit invested, while $1-\theta_{t}^{*}$ is invested in technology $u$ at $t$, yielding $\hat{w}$ units of capital per unit invested. The time $t+1$ per capita capital stock is given by the sum of these terms;

$$
\mathrm{K}_{\mathrm{t}+1}=\alpha q\left[\theta_{\mathrm{t}}^{*} \hat{\mathrm{y}}+\left(1-\theta_{\mathrm{t}}^{*}\right) \hat{\mathrm{w}}-\mathrm{r}\right]+\mathrm{r}(1-\alpha) \omega\left(\mathrm{k}_{\mathrm{t}}\right) .
$$

Converting the left-hand side of (13) into a capital-labor ratio $\left[\mathrm{K}_{t+1} /(1-\alpha)\right]$ yields

$$
\mathrm{k}_{\mathrm{t}+1}=[\alpha /(1-\alpha)] \mathrm{q}\left\{\hat{\mathrm{w}}-\mathrm{r}-(\hat{\mathrm{w}}-\hat{\mathrm{y}}) \theta_{\mathrm{t}}^{*}\right\}+\mathrm{r} \omega\left(\mathrm{k}_{\mathrm{t}}\right)
$$

Given the initial capital labor ratio $k_{0}$, equation (14) describes the evolution of the equilibrium sequence of capital stocks $\left\{\mathrm{k}_{\mathrm{t}}\right\}_{\mathrm{t}=0}^{\infty}$.

If equation (10) holds, then it is easy to confirm that equation (14) gives $k_{t+1}$ as an increasing function of $k_{\mathrm{t}}$. This function is depicted for a particular set of parameter values in the upper right-hand quadrant of Figure 1. In this figure there is a unique, asymptotically stable steady state equilibrium capital-labor ratio, denoted by $\mathrm{k}^{*} .^{10}$ If $\mathrm{k}_{\mathrm{o}}<\mathrm{k}^{*}$ holds, the capital stock-as well as the level of real activity-will rise over time as the steady state is approached. 


\section{B. Relative Monitoring Costs Rise Over Time}

As we have just described, under the appropriate technical assumptions $\left\{\mathrm{k}_{t}\right\}$ is an increasing sequence. It follows that $\left\{\psi_{\mathrm{t}+1}\right\}=\left\{\psi\left(\mathrm{k}_{\mathrm{t}+1}\right)\right\}$ is an increasing sequence as well, so that borrowers perceive effective monitoring costs that are rising over time. This fact has an important implication. If (10) holds (which it does uniformly in the examples reported by Boyd and Smith 1994d, 1995), then $\left\{\theta_{\mathrm{t}}^{*}\right\}$ is also increasing over time. Thus, as an economy moves along its growth path, an increasing fraction of investment will take place in the observable return technology. As a consequence, the development process will be accompanied by a declining (gross of verification cost) return on investment.

This shift in the composition of investment also allows for the possibility that total resources consumed in state verification decline as an economy grows. In particular, resources used in monitoring in real terms are given by $\alpha \gamma \mathrm{G}\left[\mathrm{z}\left(\theta_{\mathrm{t}}^{*} ; \psi_{\mathrm{t}+1}\right)\right]$, per capita. As $\mathrm{k}$ rises, the variable $\mathrm{z}_{\mathrm{t}}$ $=\mathrm{z}\left(\theta_{\mathrm{t}} ; \psi_{\mathrm{t}+1}\right)$ that describes the amount of monitoring can, theoretically speaking, either rise or fall. However, it is intuitive that it should fall; an intuition confirmed by all of the numerical examples reported by Boyd and Smith (1995). Thus we expect more advanced economies (ones that are "farther along their growth paths") to typically use less resources (and a smaller fraction of total resources) in dealing with financial intermediation costs. ${ }^{11}$

In this sense, then, less developed economies will appear to face financial market frictions that are more severe than those confronting their better developed counterparts. However, in the model, this is not because their financial systems are intrinsically more severely flawed; rather it is a purely endogenous outcome. In the sense described above, the evolution of financial market activity provides an economy with an increasingly more efficient set of financial 
markets as that economy develops. Less developed economies naturally tend to display relatively large costs associated with informational asymmetries.

\section{Activity in Equity Markets}

The equilibrium equity ratio $\mathrm{e}^{*} / \mathrm{q}$ may, theoretically, either increase or decrease with the growth process. However, all of the numerical examples produced by Boyd and Smith (1994d, 1995) have the property that $\mathrm{e}^{* / \mathrm{q}}$ is increasing in $\psi$. Thus, as an economy develops, capital is accumulated, and $\psi$ increases, our results suggest that the typical observed pattern should be that the volume of equity market activity increases over time. This prediction is consistent with a wealth of empirical evidence (Antje-Jovanovic, 1992, Demirguc-Kunt and Levine, 1993, 1994, Demirguc-Kunt and Maksimovic, 1995, Gurley and Shaw, 1967, Levine and Zervos, 1995, Michie, 1987) documenting the strong positive correlation between the level of activity in equity markets and real development.

In order to illustrate the theoretical co-evolution of the real and the financial sectors in the growth process predicted by our model, we now present a numerical example that is fully general equilibrium in nature. ${ }^{12}$ Given a specification of a probability distribution for w, equation (14) and the definition of $\psi\left(\mathrm{k}_{\mathrm{t}+1}\right)$ describe the equilibrium law of motion for $\mathrm{k}_{\mathrm{t}}$, which we trace out and represent diagrammatically in Figure 1 . Once $k_{t+1}$ is obtained for each value of $\mathrm{k}_{\mathrm{t}}$, we can compute the corresponding values of the equilibrium relative monitoring cost

parameter, $\psi_{t+1}$, the equilibrium composition of investment, $\theta_{t}^{*}$, the equilibrium quantity of monitoring, which is related to $z_{t}^{*}$, and the equilibrium equity ratio $e_{t}^{*} / q$. Figure 1 depicts how each of these variables evolves as the economy moves along its growth path. In addition, the total resources consumed by monitoring (measured in units of current consumption) at $\mathrm{t}$ are 
simply $\alpha \gamma \mathrm{G}\left(\mathrm{z}_{\mathrm{t}-1}^{*}\right)$. Thus it is easy to see how the resource loss implied by the existence of the credit market friction changes as an economy develops.

In order to trace out the equilibrium law of motion for $k_{\mathfrak{l}}$, it is necessary to specify a set of parameter values $(\hat{\mathrm{w}}, \hat{\mathrm{y}}, \mathrm{r}, \alpha, \mathrm{q}, \gamma)$, a production function $\mathrm{f}(\mathrm{k})$, and a probability distribution for $\mathrm{w}$. Here we assume Cobb-Douglas production, so that $\mathrm{f}(\mathrm{k})=\mathrm{Bk}^{\beta}$. In addition, we assume that $\mathrm{w}$ has the following triangular distribution:

$$
\mathrm{g}(\mathrm{w})=\begin{array}{ll}
4 \mathrm{w} / \overline{\mathrm{w}}^{2} ; & 0 \leq \mathrm{w} \leq \overline{\mathrm{w}} / 2 \\
4(\overline{\mathrm{w}}-\mathrm{w}) / \overline{\mathrm{w}}^{2} ; & \overline{\mathrm{w}} / 2 \leq \mathrm{w} \leq \overline{\mathrm{w}}
\end{array}
$$

Equation (15) yields an analytically tractable, symmetric, and unimodal distribution of returns on technology u.

Given our assumptions on the production function and the probability distribution of returns on technology $\mathrm{u}$, a specification of the vector $(\hat{\mathrm{w}}, \hat{\mathrm{y}}, \mathrm{r}, \alpha, \mathrm{q}, \gamma, \mathrm{B}, \beta)$ is sufficient to allow us to derive the values of $\mathrm{k}_{\mathrm{t}+1}, \psi_{\mathrm{t}+1}, \theta_{\mathrm{t}}^{*}$, and $\mathrm{z}_{\mathrm{t}}^{*}$ corresponding to each value of $\mathrm{k}_{\mathrm{t}}$. In addition, the determination of $\mathrm{e}_{\mathrm{t}}^{*} / \mathrm{q}$ requires that the entire probability distribution for $\mathrm{y}$ be specified.

\section{An Example}

For this example we set $\mathrm{N}=2, \mathrm{y}_{1}=0.01$, and $\mathrm{y}_{2}=4.551$, with $\mathrm{p}_{1}=\mathrm{p}_{2}=0.5$. Thus, $\hat{\mathrm{y}}=2.2805$. Equation (15) implies that $\hat{\mathrm{w}}=\overline{\mathrm{w}} / 2$. In addition, we set $\hat{\mathrm{w}}=2.5, \mathrm{r}=0.5$, $\alpha=0.5, \mathrm{q}=1.0, \gamma=0.8, \mathrm{~B}=2.0$, and $\beta=0.5$.

Figure 1 depicts various aspects of how the capital stock (or capital-labor ratio) and other equilibrium quantities evolve as an economy develops. The upper right-hand quadrant of Figure 1 represents the equilibrium law of motion for $\mathrm{k}$, given these parameter values. As noted previously, $k_{t+1}$ is a monotone increasing function of $k_{t}$. There is a unique nontrivial steady 
state equilibrium capital-labor ratio satisfying all of our hypotheses and, in addition, the steady state is asymptotically stable. The steady state value of the capital-labor ratio is approximately 2.83 , and steady state per capita output is about 1.68 .

The lower-right hand quadrant of Figure 1 depicts what the equilibrium equity ratio $\left(e_{\mathrm{t}}^{*} / \mathrm{q}\right)$ would be for each value of the current capital-labor ratio. For low enough values of $k$, the relative cost of state verification is small enough that $\theta^{*}=0$. When this occurs, all investment by borrowers is done in technology $u$, all external finance takes the form of debt, and the equilibrium quantity of equity is zero. Thus, at low current capital stocks, there is no equity market activity.

Over time, of course, $\left\{k_{t}\right\}$ will be an increasing sequence, and once $k_{t}$ is large enough (here greater than or equal to about 1.2), equity market activity will begin to be observed. The steady state equilibrium value of the equity ratio for this economy is approximately 0.1 , so this economy can-at early stages of its development-have no equity market activity. However, as it approaches its steady state, equity market activity will emerge endogenously, and ultimately equity finances a significant fraction of capital investment. ${ }^{13}$

The upper left-hand quadrant of Figure 1 shows the value of $\mathrm{z}_{\mathrm{t}}^{*}$ (the return realization below which monitoring occurs) corresponding to each value of $\mathrm{k}_{\mathrm{t}+1}$. If $\left\{\mathrm{k}_{\mathrm{t}}\right\}$ is an increasing sequence then $\left\{z_{t}^{*}\right\}$ is a decreasing sequence so that, as this economy develops, the quantity of resources expended in state verification declines. ${ }^{14}$ In this sense, the evolution of the debt and equity markets that goes on during the development process provides this economy with more efficient capital markets.

This reduction in monitoring costs is made possible by the fact that the composition of investment $\left(\theta_{\mathrm{t}}^{*}\right)$ changes along with $\mathrm{k}$. The behavior of $\theta_{\mathrm{t}}^{*}$ is displayed in the lower left-hand 
quadrant of Figure 1. As this Figure suggests, the variation of $\theta_{\mathrm{t}}^{*}$ over time is quite important in delivering the fairly intuitive result that financial market frictions consume fewer resources as an economy develops.

Of course we do not intend to imply that the share of the intermediary sector in real activity typically declines in the development process. This is obviously not the case. What we do mean to imply is that the per unit costs of intermediation typically decline as an economy develops. Such a prediction is, indeed, consistent with an array of evidence on transactions costs in developing versus developed countries (World Development Report 1989).

In our model, simplicity has dictated that a constant quantity of total investment be intermediated over time. Thus the declining unit costs of intermediation are reflected in declining total resources consumed by this activity. A richer model would allow for the total volume of real activity to grow over time; a growth which would be facilitated by a decline in unit costs.

We conclude this section by commenting on the importance in our model of the fact that the composition of investment is endogenous. If $\theta$ were exogenously fixed, (as it is in more conventional CSV environments), more resources would necessarily be employed in state verification as an economy developed. This would imply that financial market frictions loom larger as an economy develops, and it would also imply that equity market activity declines with increased real development as well. Both implications appear contrary to observation. Thus, we believe that a full understanding of the co-evolution of the real and the financial sectors in the development process requires confronting firms with an endogenous decision regarding their investment composition. 


\section{Summary}

Over time, as an economy develops, its agents become wealthier and accumulate more capital. As capital becomes relatively more abundant, its price declines. This change in relative prices has several effects. The one most central to this model is that, as the price of capital falls, the relative cost of monitoring-as perceived by borrowers-rises. This happens because we have assumed that the monitoring technology employs the final good as an input; a good whose price rises relative to capital in the growth process. However, the assumption that monitoring uses final goods is not essential to the results, although it does yield a substantial simplification. It deserves emphasis that the same forces would be at work if monitoring employed only labor, or if it employed some combination of labor and capital. Under any of these specifications, borrowers will perceive relative monitoring costs that rise with the level of development. As a consequence, borrowers substitute away from investment technologies that are monitoring-intensive (technology $\mathrm{u}$ ), and into technologies that economize on monitoring (technology o).

As discussed in the preceding section, as the allocation of investment changes so too will the optimal mix of financial claims used to finance that asset allocation. As in more standard CSV environments, debt is employed to minimize the amount of monitoring necessitated by financial contracts. As technology o is utilized more extensively, the amount of monitoring will fall of its own accord, and firms will therefore make increasing use of equity relative to debt as an economy develops.

Of course our model necessarily abstracts from a number of important issues concerning the role of financial markets in economic development. Perhaps most important among these is market integration-meaning the extent to which assets with the same risk exhibit the same 
expected rates of return. As discussed in Bekaert and Harvey (1995) market integration varies considerably across developing nations (and over time). And these differences have important implications for the level and composition of capital investment, as well as for financial contracting. However, our model cannot deal with such issues since (for tractability) we have assumed universal risk-neutrality.

\section{Toward a Set of Policy Implications}

We have yet to undertake a systematic welfare analysis of the competitive equilibrium allocations that arise in this economy. Nor have we formally analyzed the consequences of specific policy actions. However, in this section we make a few observations about the likely consequences of various policy interventions that might be contemplated in this context. ${ }^{15}$

We have displayed an example economy in which equity markets may be inactive early in the development process. This lack of equity market activity is not necessarily a signal of any allocative inefficiency, and at this phase attempts to stimulate equity market activity would, at best, simply benefit some agents at the expense of others. And, indeed, it is easy to think of interventions intended to stimulate the development of equity markets that would be positively harmful. By the same token, in an economy with active equity markets there would be no obvious case for interfering with the level of activity in these markets. Of course for developing economies it is not likely that financial (or other) markets will be operating freely from government interference. Many specific forms of government intervention can easily be analyzed in our framework, and we now offer some speculations about the consequences of certain kinds of policy interventions. 
Many government policies have the effect of altering the opportunity cost of funds perceived by borrowers. Clearly policies that affect the real rate of return to savings can be expected to do so, as can changes in the tax treatment of interest or dividend income, or various interest subsidy or loan guarantee programs.

Examples constructed in Boyd and Smith (1995) suggest that a reduction in the opportunity cost of funds tends to depress $\theta_{\mathfrak{t}}^{*}$, ceteris paribus, or in other words tends to favor the increased use of technology u. Since technology $u$ is more productive than technology o (gross of verification costs), this tends to result in more capital accumulation, and in a corresponding upward shift in the law of motion for the capital stock. It also tends to attenuate the level of equity market activity. Thus policies that reduce the opportunity cost of funds to borrowers are likely to depress the level of activity in equity markets, and to increase the reliance on debt finance.

\section{Inflation}

A particularly obvious macroeconomic factor that affects the opportunity cost of funds to borrowers is the rate of inflation. Obviously higher rates of inflation act to reduce the real rate of return on real balances, or on any other savings instrument bearing a fixed nominal return. In addition, particularly in many developing countries, binding nominal interest rate ceilings limit the flexibility of nominal returns, and relatively high reserve requirements force banks to hold large amounts of real balances. Both kinds of factors will tend to allow increases in the rate of inflation to put downward pressure on real returns to savings. Indeed, Boyd, Choi, and Smith (1995) document that-in several countries-the real rate of return on both "safe" savings instruments, and on equity, is very strongly negatively correlated with the rate of inflation. 
Thus, higher rates of inflation will tend to reduce the real returns perceived by savers, and to lower the opportunity cost of funds to borrowers.

Our previous observations, then, suggest that higher rates of inflation are likely to reduce $\theta_{t}^{*}$, and hence to depress the volume of activity in equity markets. This conjecture that high inflation is detrimental to equity market activity is consistent with the finding of Tun Wai and Patrick (1973), Choi, Smith, and Boyd (1995), and Boyd, Levine, and Smith (1995) that higher rates of inflation do tend to be injurious to stock market operations. ${ }^{16}$ Moreover, if we are correct, higher rates of inflation lead to heavier use of the investment technology that is subject to the CSV problem, and to a greater volume of resources being consumed by state verification. In this sense, higher rates of inflation would appear to make an economy's financial markets function less efficiently. Thus macroeconomic policies that are conducive to price stability will tend to favor the development of equity markets, and to foster the efficient operation of capital markets in general. ${ }^{17}$

There are, of course, any number of other methods by which government interventions can be used to reduce the opportunity cost of funds to borrowers. For instance, a reduction in ceiling rates of interest paid on deposits would tend to do so, as would an increase in the effective tax rate on capital income. Our previous reasoning suggests that these actions would tend to shift the composition of investment in favor of technology u. This would typically favor increased capital formation, ${ }^{18}$ and it would also tend to reduce the volume of equity market activity. In addition, as before, it would tend to lead to more resources being consumed in the state verification process. In this sense, high real returns to savers tend to be conducive to the development of equity markets, and to economizing on the resources consumed by monitoring. 


\section{The Relation Between Debt and Equity Markets}

A final issue of government policy concerns the relationship between debt and equity markets. It is often argued that the allocative importance of equity markets in developing economies is not very great, as debt markets constitute an effective substitute for them. ${ }^{19} \mathrm{We}$ believe that this argument is called into serious question by our analysis. In particular, by using equity markets appropriately, firms in our model substantially reduce their costs of issuing debt. Indeed, Boyd and Smith (1994d) produce examples in which it is impossible for firms to issue debt without issuing some equity, simply because the costs of 100 percent debt finance are too great for this to be feasible. This situation is most likely to obtain as economies become relatively developed, and it suggests that-at some levels of development-equity markets will be a necessary complement to debt markets. When this occurs, equity market activity will appear endogenously, if it is not hampered by government intervention.

\section{Conclusions}

We have developed a model in which capital is produced by investors who make use of two technologies. One yields a high expected return, but is subject to an informational friction. The other yields a lower expected return, but has the advantage of full public observability. Investors must make a decision regarding how heavily they will utilize each technology. This decision depends, among other things, on the relative price between capital and the resources used in state verification.

As an economy moves along its growth path, investors will perceive a relative cost of

monitoring that rises over time. As a result, under conditions that we typically expect to prevail, less use will be made of the unobservable return, and more use will be made of the 
observable return technology. Since investment in the unobservable return technology is generally associated with the use of debt finance-while the use of the observable return technology is associated with equity-we also typically expect the ratio of equity finance to rise an economy develops. This intuition is confirmed by all of the examples in Boyd and Smith (1994d, 1995).

Moreover, as we have seen, it is possible to produce parameter values such that-at low levels of development-there will be no use of equity markets. Equity market activity can be observed for such parameters only once the economy attains a critical level of real development. Such examples support the conclusion of Gurley and Shaw (1960, p. 92) that "the selection of financial assets evolves in the growth process," and that the variety of financial claims increases as well.

It is also the case that, in all of our numerical examples the quantity of resources consumed by monitoring declines as an economy develops. This provides a sense in which the endogenous evolution of debt and equity markets in the development process provides an economy with a more efficient set of capital markets.

- Finally, our analysis provides a sense in which debt and equity markets function as complements rather than substitutes. A case against the importance of equity markets in financing real development is often made on the basis that existing credit markets are close substitutes for equity markets. Our analysis calls the validity of such arguments into serious question. 
Footnotes

${ }^{1}$ Examples of the kind of literature we have in mind include Greenwood and Jovanovic (1990), Bencivenga and Smith (1991), Cooley and Smith (1992), or Levine (1991) and Becivenga, Smith, and Starr (1994a, b, c). In the first three papers all investment is financed by bank lending, in the last four all investment is financed either internally, or by issuing equity. Of this literature, only Greenwood and Jovanovic (1990) has a volume of financial market activity that explicitly evolves over time.

${ }^{2}$ Specifically, Diamond (1984), Gale and Hellwig (1985), and Williamson (1986).

${ }^{3}$ If the expected amount of capital produced by the observable return technology is higher than that produced by the unobservable return technology, then the latter technology is dominated and will never be utilized. This would leave us with a model where the ModiglianiMiller theorem applies.

${ }^{4}$ Specifically, that of Section 5 of this paper, and of Section 6 of Boyd and Smith (1995).

${ }^{5}$ It is assumed that external investors can observe both $\dot{i}_{\mathfrak{t}}$, and the allocation of investments among the two investment technologies.

${ }^{6}$ Note the we abstract from stochastic monitoring. See Boyd and Smith (1994a) for a defense.

${ }^{7}$ Monitoring uses $\gamma$ units of final goods and services; $\gamma / \mathrm{q}$ is this cost relative to the size of individual investment projects. Dividing this quantity by the relative price of capital gives monitoring costs measured in units of capital. Since investment project yield capital, this puts monitoring costs and investment returns in comparable units.

${ }^{8}$ In the CSV literature payments which are not contingent on firm performance in nonverification states are associated with "debt." In addition, Boot and Thakor (1993) term 
securities which utilize information (here about y) "equity," while securities that do not utilize information about firm performance are termed "debt." Both terminologies are consistent with our usage of the terms debt and equity.

It should be noted that none of our analysis is inconsistent with the possibility that a firm's debt—or even equity—is held by intermediates.

${ }^{9}$ The latter is not essential, as we discuss in more detail below.

${ }^{10}$ Boyd and Smith (1995) shows that, if $(10)$ and $\hat{y} \alpha q \geq \underline{k}(1-\alpha)$ hold, then there necessarily exists at least one asymptotically stable steady state equilibrium with $(1-\alpha) \mathrm{w}\left(\mathrm{k}^{*}\right)>\alpha q$. Any such steady state equilibrium is approached monotonically.

${ }^{11}$ Because our model has a fixed quantity of total resources $(\alpha \mathrm{q})$ always being transferred to entrepreneurs, the analysis does not distinguish between a decline in the unit costs of intermediation, and a decline in the total costs of intermediation. A more general analysis would have more funds being transferred in financial markets as an economy develops. Such an analysis would then predict that the unit costs of intermediation fall with development, although the behavior of total costs would depend on the rate of growth of intermediary activity.

${ }^{12}$ This example is drawn from Boyd and Smith (1995).

${ }^{13}$ For this example market capitalization is about 3 percent of GNP in the steady state. This approximates observed market capitalizations in Pakistan and Turkey (see Table 1).

${ }^{14}$ This property is shared by all of the examples reported in Boyd and Smith (1995).

${ }^{15} \mathrm{~A}$ technical observation is that competitive equilibrium allocations in our economy are what Balasko and Shell (1980) term "weakly Pareto Optimal;" that is, it is not possible to achieve a Pareto improvement by transferring resources between a finite number of generations. However, this does not imply that competitive equilibrium allocations are fully Pareto optimal; 
capital overaccumulation is still possible, as it is in the standard Diamond (1965) model. If our economy does not display capital overaccumulation — that is, if steady state real interest rates are not too low-and if there are no other interventions, then competitive equilibria will be Pareto optimal, and any policy interventions that are not entirely negative in their consequences must necessarily be redistributive. In this situation, policies must be evaluated with respect to whether these redistributions are deemed socially desirable.

${ }^{16}$ At this point we withhold any conjectures about the effects of higher inflation on real activity. An analysis of this issue would require a monetary version of the present model. This is a sufficiently large modification that we do not currently want to speculate about the consequences of higher inflation for, say, the steady state capital stock.

${ }^{17}$ For further theoretical results on this point, see Choi, Smith, and Boyd (1995), or Boyd and Smith (1994c).

${ }^{18}$ This conclusion depends on savings rates being sufficiently insensitive to variations in the real (after tax) rate of interest; an assumption that is obviously made in our formal analysis.

${ }^{19}$ See, for instance, the discussion in Rojas-Suarez and Weisbrod (1994). 
References

Antje, Raymond, and Jovanovic, Boyan. 1992. Stock markets and development. Manuscript. New York University.

Balasko Yves, and Shell, Karl. 1980. The overlapping generations model: The case of pure exchange without money. Journal of Economic Theory 23, 281-306.

Bekaert, Geert, and Harvey, Campell, R. 1995. Time-varying world market integration. Journal of Finance L, 2, 403-45.

Bencivenga, Valerie R., and Smith, Bruce D. 1991. Financial intermediation and endogenous growth. Review of Economic Studies 58, 195-209.

Bencivenga, Valerie R., Smith, Bruce D., and Starr, Ross M. 1994a. Liquidity of secondary capital markets: Allocative efficiency and the maturity composition of the capital stock. Economic Theory, forthcoming.

- 1994b. Transactions costs, technological choice, and endogenous growth. Journal of Economic Theory, forthcoming.

. 1994c. Liquidity of secondary capital markets, capital accumulation, and the term structure of asset yields. Manuscript. Cornell University.

Bernanke, Ben S., and Gertler, Mark. 1989. Agency costs, net worth, and business fluctuations. American Economic Review 79, 14-31.

Boot, Arnoud and Thakor, Anjan. 1993. Security design. Journal of Finance 48, 1349-78.

Boyd John H., and Prescott, Edward C. 1986. Financial intermediary coalitions. Journal of Economic Theory. 
Boyd, John H., and Smith, Bruce D. 1994a. How good are standard debt contracts? Stochastic versus nonstochastic monitoring in a costly state verification environment. Journal of Business, forthcoming.

. 1994b. Capital market imperfections, international credit markets, and nonconvergence. Manuscript. Federal Reserve Bank of Minneapolis.

. 1994c. Capital market imperfections in a monetary growth model. Manuscript. Federal Reserve Bank of Minneapolis.

. 1994d. The use of debt and equity in optimal financial contracts. Manuscript. Federal Reserve Bank of Minneapolis.

. 1995. The evolution of debt and equity markets in economic development. Manuscript. Federal Reserve Bank of Minneapolis.

Chang, Chun. 1987. Capital structure as optimal contracts. Manuscript. University of Minnesota.

Choi, Sangmok; Smith, Bruce D.; and Boyd, John H. 1995. Inflation, financial markets, and capital formation. Manuscript. Federal Reserve Bank of Minneapolis.

Cooley, Thomas F., and Smith, Bruce D. 1992. Financial markets, specialization, and learning by doing. Manuscript. Cornell University.

Demirguc-Kunt, Asli, and Levine, Ross. 1993. Stock market development and financial intermediary growth: A research agenda. Manuscript. The World Bank.

- 1994. Stock markets and financial intermediaries: Stylized facts. Manuscript. The World Bank.

Demirguc-Kunt, Asli, and Maksimovic, Vojislav. 1995. Stock market development and firm financing choices. Manuscript. The World Bank. 
Dewatripont, Mathias, and Tirole, Jean. A theory of debt and equity: Diversity of securities and manager-shareholder congruence. Quarterly Journal of Economics, (forthcoming).

Diamond, Douglas W. 1984. Financial intermediation and delegated monitoring. Review of Economic Studies 51, 393-414.

Diamond, Peter A. 1965. National debt in a neoclassical growth model. American Economic Review 55.

Gale, Douglas, and Hellwig, Martin. 1985. Incentive-compatible debt contracts: The oneperiod problem. Review of Economic Studies 52, 647-63.

Greenwood, Jeremy, Hercowitz, Zvi, and Krussell, Per. 1995. Long-run implications of investment-specific technological change. Manuscript. University of Rochester.

Gurley, John G., and Shaw, Edward S. 1955. Financial aspects of economic development. American Economic Review 45, 515-38.

. 1960. Money in a theory of finance. Brookings Institute, Washington, D.C. . 1967. Financial structure and economic development. Economic Development and Cultural Change 15, 257-68.

Hamid, Javed, and Singh, Ajit. 1992. Corporate financial structures in developing countries. Technical Paper 1. International Finance Corporation.

Krasa, Stefan, and Villamil, Anne P. 1992. Monitoring the monitor: An incentive structure for a financial intermediary. Journal of Economic Theory 57, 197-221.

Levine, Ross. 1991. Stock markets, growth, and tax policy. Journal of Finance 46, 1445-65. Levine, Ross, and Zervos, Sara. 1995. Policy, stock market development, and long-run growth. Manuscript. The World Bank. 
McKinnon, Ronald I. 1973. Money and capital in economic development. Brookings Institute, Washington, D.C.

Michie, R. C. 1987. The London and New York Stock Exchanges, 1850-1914. Allen and Unwin. London.

Rojas-Suarez, Liliana, and Weisbrod, Stephen. 1994. Financial market fragilities in Latin America: From banking crisis resolution to current policy challenges. Manuscript. International Monetary Fund.

Seward, James K. 1990. Corporate financial policy and the theory of financial intermediation. Journal of Finance 45, 351-77.

Shaw, Edward C. 1973. Financial deepening in economic development. New York: Oxford University Press.

Townsend, Robert M. 1979. Optimal contracts and competitive markets with costly state verification. Journal of Economic Theory 21, 265-93.

Tun Wai, U., and Patrick, Hugh T. 1973. Stock and bond issues and capital markets in less developed countries. International Monetary Fund Staff Papers 20, 253-317.

Watson, C., Maxwell, G., Kincaid, R., Atkinson, C., Kalter, E., and Folkerts-Landau, D. 1986. International capital markets: Developments and markets. International Monetary Fund, World Economic and Financial Surveys.

Williamson, Stephen D. 1986. Costly monitoring, financial intermediation, and equilibrium credit rationing. Journal of Monetary Economics 18, 159-79.

World Bank. 1989. World development report 1989. New York: Oxford University Press. 
Table 1

Average Market Capitalization (Percent of GDP)*

\begin{tabular}{|c|c|}
\hline Hong Kong & 1.26 \\
\hline Japan & .98 \\
\hline Germany & .24 \\
\hline United Kingdom & .86 \\
\hline United States & .61 \\
\hline Singapore & .95 \\
\hline Switzerland & .75 \\
\hline South Africa & 1.35 \\
\hline Malaysia & .88 \\
\hline Korea & .22 \\
\hline Thailand & .21 \\
\hline Netherlands & .46 \\
\hline Australia & .49 \\
\hline Canada & .46 \\
\hline Sweden & .43 \\
\hline Mexico & .10 \\
\hline Jordan & .48 \\
\hline India & .07 \\
\hline Norway & .18 \\
\hline Austria & .08 \\
\hline Brazil & .11 \\
\hline France & .23 \\
\hline Spain & .21 \\
\hline New Zealand & .38 \\
\hline Belgium & .31 \\
\hline Italy & .15 \\
\hline Finland & .17 \\
\hline Zimbabwe & .10 \\
\hline Pakistan & .04 \\
\hline Turkey & .05 \\
\hline
\end{tabular}

*Values are 1980-91 averages.

Source: Demirguc-Kunt and Maksimovic (1995).

${ }^{1}$ Examples of the kind of literature we have in mind include Greenwood and Jovanovic 
(1990), Bencivenga and Smith (1991), Cooley and Smith (1992), or Levine (1991) and Bencivenga, Smith, and Starr (1994a, b, c). In the first three papers all investment is financed by bank lending, in the last four all investment is financed either internally, or by issuing equity. Of this literature, only Greenwood and Jovanovic (1990) has a volume of financial market activity that explicitly evolves over time. 
Figure 1

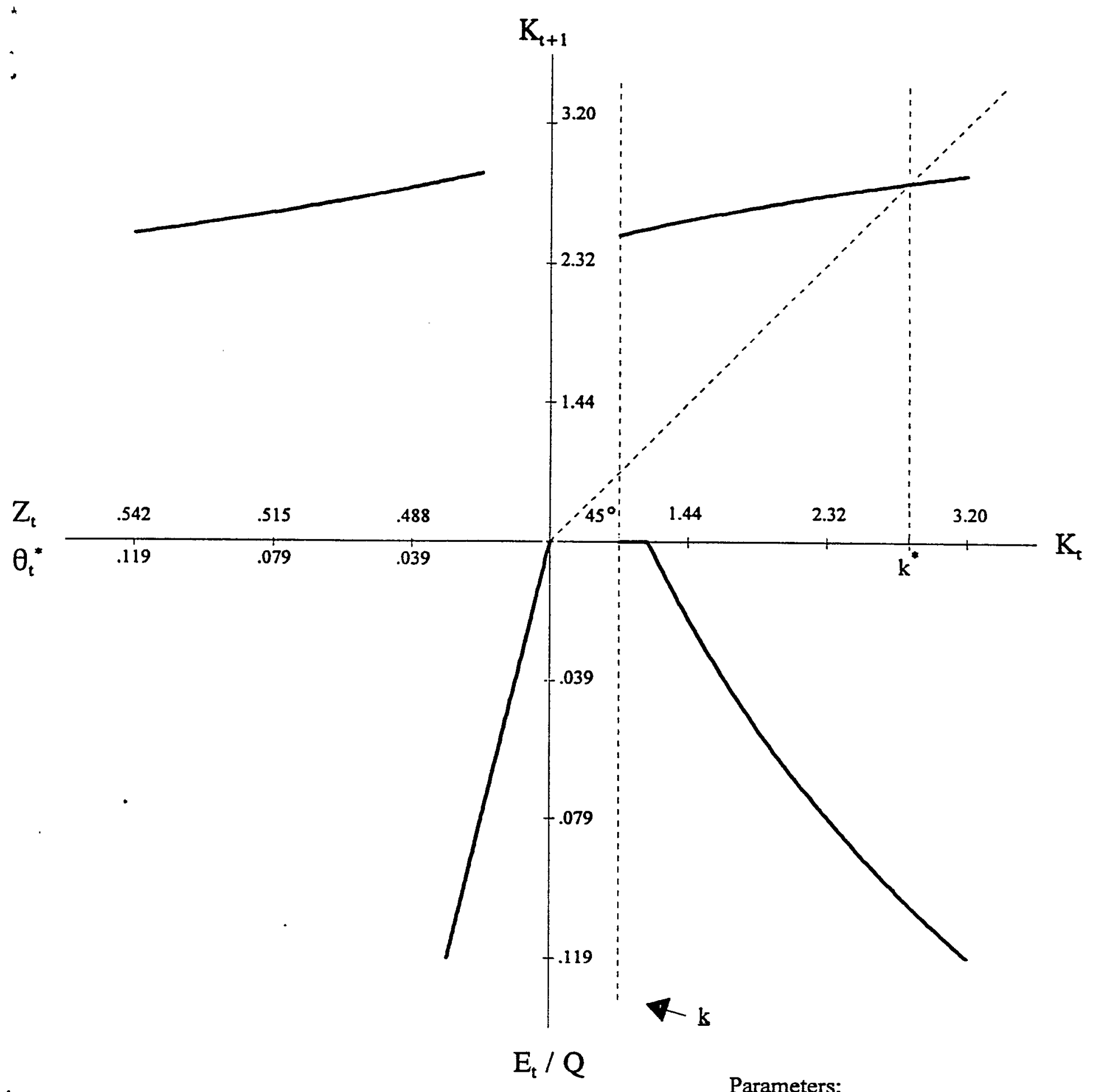

Parameters:

$$
\begin{array}{ll}
w=2.5 & q=1.0 \\
\hat{\gamma}=2.2805 & \gamma=0.8 \\
r=0.5 & \alpha=0.5 \\
B=2.0 & \beta=0.5
\end{array}
$$

